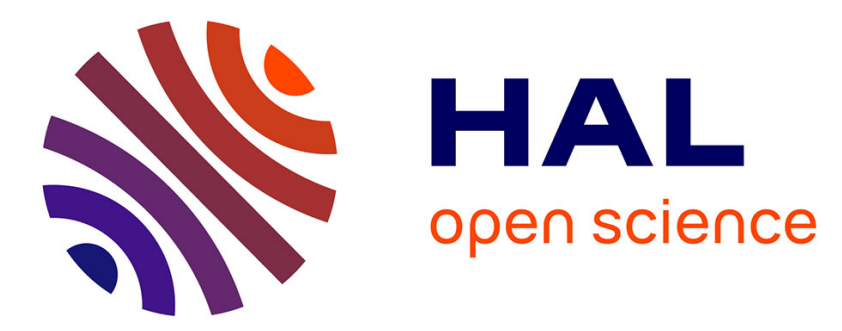

\title{
Stable 16-electron, paramagnetic cyclopentadienylmolybenum(II) complexes
}

Fatima Abugideiri, D. Webster Keogh, Rinaldo Poli

\section{To cite this version:}

Fatima Abugideiri, D. Webster Keogh, Rinaldo Poli. Stable 16-electron, paramagnetic cyclopentadienylmolybenum(II) complexes. Journal of the Chemical Society, Chemical Communications, 1994, 20, pp.2317-2318. 10.1039/C39940002317 . hal-03532950

\section{HAL Id: hal-03532950 https://hal.science/hal-03532950}

Submitted on 18 Jan 2022

HAL is a multi-disciplinary open access archive for the deposit and dissemination of scientific research documents, whether they are published or not. The documents may come from teaching and research institutions in France or abroad, or from public or private research centers.
L'archive ouverte pluridisciplinaire HAL, est destinée au dépôt et à la diffusion de documents scientifiques de niveau recherche, publiés ou non, émanant des établissements d'enseignement et de recherche français ou étrangers, des laboratoires publics ou privés. 


\title{
Stable 16-electron, Paramagnetic Cyclopentadienylmolybenum(II) Complexes
}

\author{
Fatima Abugideiri, D. Webster Keogh and Rinaldo Poli* \\ Department of Chemistry and Biochemistry, University of Maryland, College Park, Maryland 20742, USA
}

Complexes $\left[\mathrm{C}_{5} \mathrm{Me}_{5} \mathrm{MoClL}_{2}\right]$ ( $\mathrm{L}=$ tertiary phosphine) are rare examples of stable cyclopentadienylmolybdenum(II) 16 -electron complexes and the first such complexes with a spin triplet ground state.

$\mathrm{Mo}^{\text {Il }}$ complexes having one cyclopentadienyl ligand or a substituted analogue are a very well represented class of compounds. ${ }^{1}$ Typically, they are electronically saturated (18-valence electron) and contain one or more carbonyl ligand, e.g. $\left[\mathrm{C}_{5} \mathrm{H}_{5} \mathrm{MoX}(\mathrm{CO})_{3}\right], \quad\left[\mathrm{C}_{5} \mathrm{H}_{5} \mathrm{MoX}(\mathrm{CO})_{2} \mathrm{~L}\right]$, $\left[\mathrm{C}_{5} \mathrm{H}_{5} \mathrm{MoX}(\mathrm{CO}) \mathrm{L}_{2}\right]$, although $\mathrm{CO}-$ free analogues are also known, e.g. [(ring)MoX $\left.\left(\mathrm{PMe}_{3}\right)_{3}\right]$ (ring $=\mathrm{C}_{5} \mathrm{H}_{5}, \mathrm{C}_{5} \mathrm{H}_{4} \mathrm{R}$, $\mathrm{C}_{5} \mathrm{Me}_{5} ; \mathrm{X}=\mathrm{H}$, alkyl, halogen). ${ }^{2}$ Electronically unsaturated complexes with a 16-electron configuration that derive from ligand dissociation from these systems are reactive intermediates and usually rapidly add a two-electron donor or engage in oxidative addition processes, including those involving $\mathrm{C}-\mathrm{H}$ bonds. ${ }^{2 b .2 c .3}$ Compounds $\left[\mathrm{C}_{5} \mathrm{H}_{5} \mathrm{Mo}(\mathrm{CO})_{2} \mathrm{X}\right]\left(\mathrm{X}=\mathrm{AsBu}_{2}{ }_{2}\right.$, $\left.\mathrm{POCMe}_{2} \mathrm{CMe}_{2} \mathrm{O}\right)^{4}$ and $\left[\mathrm{C}_{5} \mathrm{Me}_{5} \mathrm{MoX}\left(\mathrm{PMe}_{3}\right) \mathrm{L}\right]\left(\mathrm{X}=\mathrm{PCy}_{2}, \mathrm{~L}\right.$ $\left.=\mathrm{PMe}_{3} ; \mathrm{X}=\mathrm{PPh}_{2}, \mathrm{~L}=\mathrm{PMe}_{3}, \mathrm{PHPh}_{2}\right)^{5}$ are rare examples of unsaturated systems that can be isolated under normal laboratory conditions. These diamagnetic compounds probably owe their stability to additional $\pi$-donation from the terminal X ligand into the metal empty orbital (see Scheme 1, part a) and/or to the steric protection by the bulky substituents. The analogous compound $\left[\mathrm{C}_{5} \mathrm{H}_{5} \mathrm{MoCl}(\mathrm{CO})_{2}\right]$, on the other hand, has only been obtained in methane or argon matrices. ${ }^{6}$ Here, we report the synthesis, properties and preliminary reactivity studies of a new class of stable 16electron Moll complexes, the paramagnetic $\left[\mathrm{C}_{5} \mathrm{Me}_{5} \mathrm{MoCl}_{2}\right]$ complexes $(\mathrm{L}=$ tertiary phosphine $)$.

Complexes $\left[\mathrm{C}_{5} \mathrm{Me}_{5} \mathrm{MoClL}_{2}\right]\left(\mathbf{1 a}, \mathrm{L}=\mathrm{PMe}_{3} ; \mathbf{1 b}, \mathrm{PMe}_{2} \mathrm{Ph}\right)$ can be obtained in solution as shown in Scheme 2, e.g. by sodium reduction of higher-valent precursors in THF in the presence of a stoichiometric amount of the phosphine ligand and under an atmosphere of argon. $\dagger$ It has been reported that a similar reduction of $\left[\mathrm{C}_{5} \mathrm{Me}_{5} \mathrm{MoCl}_{4} / 3 \mathrm{PMe}_{3}\right]$ under argon yields instead the saturated derivative, $\left[\mathrm{C}_{5} \mathrm{Me}_{5} \mathrm{MoCl}\left(\mathrm{PMe}_{3}\right)_{3}\right]$ $2,{ }^{2 b}$ while reduction under $\mathrm{N}_{2}$ results in $\left[\mathrm{C}_{5} \mathrm{Me}_{5} \mathrm{MoCl}(\mathrm{P}\right.$ $\left.\left.\mathrm{Me}_{3}\right)_{2}\left(\mathrm{~N}_{2}\right)\right]$ 3. ${ }^{5}$ Compounds 1 are highly soluble and could not be crystallized from concentrated heptane solutions at $-80^{\circ} \mathrm{C}$. Solutions of these compounds are indefinitely stable at room temperature under argon. Their stoichiometry is confirmed by the derivatization reactions discussed below. The ${ }^{1} \mathrm{H}$ NMR spectra $\dagger$ underline the paramagnetism of compounds $\mathbf{1}$ and the magnetic moment determined for 1 a at room temperature

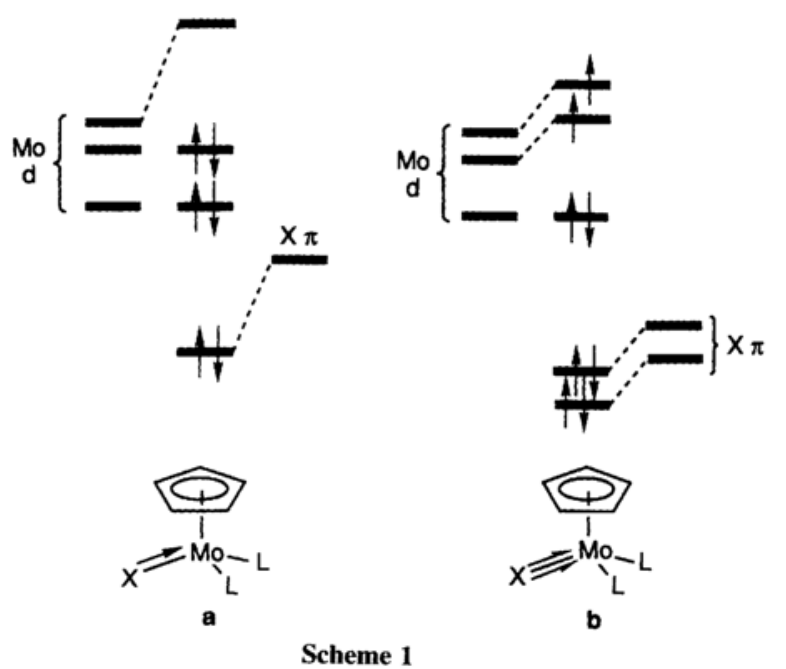

by the NMR method is consistent with the presence of two unpaired electrons. Linear $\delta v s .1 / T$ plots in the range of -40 $<T<20^{\circ} \mathrm{C}$ for all resonances indicate Curie behaviour. The same ${ }^{1} \mathrm{H}$ NMR properties are observed in $\left[{ }^{2} \mathrm{H}_{6}\right]$ benzene and $\left[{ }^{2} \mathrm{H}_{6}\right]$ acetone, therefore no 18 -electron acetone adduct is formed.

Preliminary reactivity studies of compounds 1 are illustrated in Scheme 2. By addition of $\mathrm{N}_{2}$ or $\mathrm{CO}$ or by oxidative addition of $\mathrm{H}_{2}$, complexes 3, $\left[\mathrm{C}_{5} \mathrm{Me}_{5} \mathrm{MoCl}(\mathrm{CO}) \mathrm{L}_{2}\right]\left(\mathbf{4 a}, \mathrm{L}=\mathrm{PMe}_{3} ; \mathbf{4 b}\right.$, $\left.\mathrm{L}=\mathrm{PMe}_{2} \mathrm{Ph}\right) \ddagger$ and $\left[\mathrm{C}_{5} \mathrm{Me}_{5} \mathrm{MoClH}_{2} \mathrm{~L}_{2}\right]\left(5 \mathbf{a}, \mathrm{L}=\mathrm{PMe}_{3} ; \mathbf{5 b}, \mathrm{L}\right.$ $\left.=\mathrm{PMe}_{2} \mathrm{Ph}\right), \S$ are quantitatively obtained. Complexes 5 are analogous to the previously described $\left[\left(\eta-\mathrm{C}_{5} \mathrm{H}_{4}-\mathrm{Pr}^{\mathrm{i}}\right) \mathrm{MoClH}_{2-}\right.$ $\left.\left(\mathrm{PMe}_{3}\right)_{2}\right] \cdot{ }^{3}$ The addition of $\mathrm{N}_{2}$ (545 Torr) to 1a is relatively slow at $37{ }^{\circ} \mathrm{C}\left[k_{\text {obs }}=(3.75 \pm 0.03) \cdot 10^{-4} \mathrm{~s}^{-1}\right]$ but the corresponding additions of $\mathrm{H}_{2}$ and $\mathrm{CO}$ are substantially faster $\left[\mathrm{H}_{2}\right.$ : 673 Torr, $T=12^{\circ} \mathrm{C}, k=(1.53 \pm 0.07) \cdot 10^{-2} \mathrm{~s}^{-1} ; \mathrm{CO}: 673$ Torr, $\left.T=12^{\circ} \mathrm{C}, k=(1.45 \pm 0.07) \cdot 10^{-2} \mathrm{~s}^{-1}\right] .3$ loses $\mathrm{N}_{2}$ upon gentle heating under vacuum to afford mostly $1 \mathrm{a}$. The addition of $\mathrm{PMe}_{3}$ to $1 \mathrm{a}$ at $50{ }^{\circ} \mathrm{C}$ slowly produces a small equilibrium amount of 2 (no interaction occurs at room temp. over two weeks), and a similar mixture of $1 \mathbf{a}$ (major), $\mathbf{2}$ (minor) and free $\mathrm{PMe}_{3}$ is also obtained under the same conditions by approaching the equilibrium from the other direction. A slow competitive thermal decomposition of the 16-electron complex (see below) prevents accurate thermodynamic parameters being determined for this equilibrium. However, it is clear that the equilibrium lies in favour of the 16-electron complex.

It is interesting to observe that compounds $\mathbf{2}$ and $\mathbf{3}$ were obtained ${ }^{2 b}, 5$ by room temp. sodium reduction of $\mathrm{C}_{5} \mathrm{Me}_{5} \mathrm{MoCl}_{4}$ in the presence of $\mathrm{PMe}_{3}$ or $\mathrm{PMe}_{3} / \mathrm{N}_{2}$. $\int$ The lack of reaction between $1 \mathrm{a}$ and $\mathrm{PMe}_{3}$ to form 2 under these conditions (see above) suggests that the synthesis of 2 from the $\mathrm{C}_{5} \mathrm{Me}_{5} \mathrm{MoCl}_{4} /$ $3 \mathrm{Na} / 3 \mathrm{PMe}_{3}$ system must involve coordination of the three $\mathrm{PMe}_{3}$ molecules to a higher oxidation state precursor followed by reduction. It is also interesting to compare the stability of 1 with the reported formation of compound $\left[\mathrm{C}_{5} \mathrm{Me}_{5} \mathrm{WClH}(\mathrm{P}\right.$ $\left.\mathrm{Me}_{3}\right)\left(\mathrm{CH}_{2} \mathrm{PMe}_{2}\right)$ ], 6 , by the sodium reduction of $\mathrm{C}_{5} \mathrm{Me}_{5} \mathrm{WCl}_{4}$ with 3 equiv. of $\mathrm{Na}$ in the presence of $\mathrm{PMe}_{3} \cdot{ }^{5} \mathrm{It}$ is reasonable to postulate that this $\mathrm{W}$ product arises from the intramolecular $\mathrm{C}-\mathrm{H}$ oxidative addition of $\mathrm{PMe}_{3}$ to an unobserved $\left[\mathrm{C}_{5} \mathrm{Me}_{5} \mathrm{WCl}\left(\mathrm{PMe}_{3}\right)_{2}\right]$ intermediate (the $\mathrm{W}$ analogue of $1 \mathrm{a}$ ). Warming compound 1a in $\mathrm{C}_{6} \mathrm{D}_{6}$ results in slow decomposition with formation of $\left[\mathrm{C}_{5} \mathrm{Me}_{5} \mathrm{MoCl}_{2}\left(\mathrm{PMe}_{3}\right)_{2}\right]$ and $\mathrm{C}_{5} \mathrm{Me}_{5} \mathrm{MoD}$ $\left(\mathrm{PMe}_{3}\right)_{3}$ as the only identified species but no diamagnetic Mo analogue of 6 .

The stability and magnetic properties of complexes 1 could be rationalized in two alternative and complimentary ways. Thinking as an organometallic chemist (covalent bonding, 18 -electron rule), 1 can gain stability by $\pi$-donation through the $\mathrm{Cl}$ lone pairs (see Scheme 1, part b). Since $\mathrm{Cl}$ is a double-sided $\pi$ donor, it will be capable of interacting with and

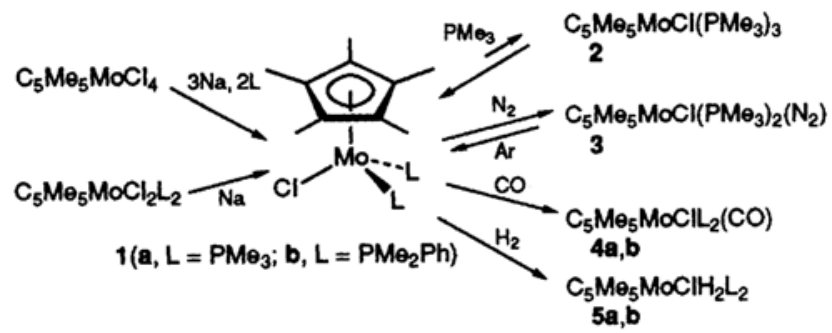

Scheme 2 
raising the energy of two of the frontier metal orbitals, whereas a single-sided $\pi$ donor like a phosphido or arsenido group would raise the energy of only one orbital (Scheme 1, part a), resulting in a different spin state preference for the two systems. The stabilization by $\pi$ donation from $\mathrm{Cl}$ is in principle equally effective irrespective of the spin state. In the pictorial representation of $\mathbf{1}$ as in Scheme 1, part b, each half-arrow stands for a two-orbital three-electron interaction. Thinking as a coordination chemist (ligand field theory), on the other hand, one recognizes a pseudo-octahedral coordination and the isolobal analogy $\left[\mathrm{C}_{5} \mathrm{Me}_{5} \stackrel{\mathrm{O}}{\longleftrightarrow} \mathrm{Cl}\left(\mathrm{PMe}_{3}\right)_{2}\right]$ with the known [trans- $\left.\mathrm{MoCl}_{2}\left(\mathrm{PMe}_{3}\right)_{4}\right]$ complex, which is also paramagnetic and this can be easily understood on the basis of the known octahedral electronic structure. ${ }^{7} \mathrm{~A}$ small splitting of the octahedral $\mathrm{t}_{2 \mathrm{~g}}$ set for 1 because of the low symmetry $\left(C_{S}\right)$ is expected and the diamagnetism of, say, $\left[\mathrm{C}_{5} \mathrm{Me}_{5} \mathrm{Mo}\right.$ $\left.\left(\mathrm{PCy}_{2}\right)\left(\mathrm{PMe}_{3}\right)_{2}\right]$ can be rationalized, in ligand field terms, as the result of a reduced pairing energy owing to the lower electronegativity of the phosphido ligand with respect to $\mathrm{Cl}$. The achievement of a seven-coordinate geometry seems under steric control, as indicated by the quantitative reaction of 1a with $\mathrm{CO}, \mathrm{N}_{2}$ and $\mathrm{H}_{2}$, but not with $\mathrm{PMe}_{3}$. However, $\mathrm{PMe}_{3}$ is the strongest $\sigma$ donor and thus the formation of the electron-rich tris- $\left(\mathrm{PMe}_{3}\right)$ complex could also be disfavoured for electronic reasons. By analogy, $\left[\right.$ trans $\left.-\mathrm{MoCl}_{2}\left(\mathrm{PMe}_{3}\right)_{4}\right]$ adds $\mathrm{CO}$ but not $\mathrm{PMe}_{3}{ }^{7}$

There are other known classes of piano-stool 16-electron complexes, such as the four-legged $\mathrm{C}_{5} \mathrm{H}_{5} \mathrm{Mo}^{\mathrm{IV}} \mathrm{L}_{4}($ all $S=1),{ }^{8}$ $\mathrm{C}_{5} \mathrm{H}_{5} \mathrm{Nb}^{111} \mathrm{~L}_{4}$ (either $S=0$ or $\left.S=1\right)^{9}$ and (triene) $\mathrm{Zr}^{111} \mathrm{~L}_{4}$ (all $S$ $=0)^{10}$ and two-legged $\mathrm{C}_{5} \mathrm{Me}_{5} \mathrm{Ru}^{11} \mathrm{~L}_{2}$ (all $S=0$ ). ${ }^{11}$ Compounds 1 are the first paramagnetic representatives of the threelegged piano stool $\mathrm{C}_{5} \mathrm{H}_{5} \mathrm{Mo}^{11} \mathrm{~L}_{3}$ class. To the best of our knowledge, they are also the lowest oxidation state organometallic 16-electron $S=1$ complexes that are stable under normal laboratory conditions.|

We are grateful to the Donors of the Petroleum Research Fund for partial support of this work. Additional support from the National Science Foundation and the Alfred P. Sloan Foundation through awards to R. P. is also gratefully acknowledged.

Received, 8th June 1994; Com. 4/03472D

\section{Footnotes}

$\uparrow$ By carrying out all operations under argon, $\left[\mathrm{C}_{5} \mathrm{Me}_{5} \mathrm{MoCl}_{4}\right](0.511$ g mg, $1.37 \mathrm{mmol}$ ) was added to a Schlenk tube which contained THF $(40 \mathrm{ml})$, amalgamated $\mathrm{Na}(98 \mathrm{mg}, 4.26 \mathrm{mmol}$ in $9 \mathrm{~g} \mathrm{Hg})$ and $\mathrm{PMe}_{3}(284$ $\mu \mathrm{l}, 2.74 \mathrm{mmol}$ ). Complete conversion to $1 \mathrm{a}$ (' $\mathrm{H}$ NMR monitoring) requires $24 \mathrm{~h}$ stirring at room temp. The mixture was evaporated to dryness and the residue extracted with heptane until the washings were colourless $(25 \mathrm{ml})$. Aliquots of the solution were used for further reactivity studies and for the magnetic moment measurements, the concentration of 1a being determined by reacting an aliquot of the solution with $\mathrm{H}_{2}$ to afford compound $\mathbf{5 a}$ and gas-volumetrically measuring the amount of gas absorbed. Based on the result of this procedure, the yield of 1a was $41 \% .{ }^{1} \mathrm{H} N M R\left(\mathrm{C}_{6} \mathrm{D}_{6}, T 291 \mathrm{~K}, \delta\right): 44.8$ (br s, $\mathrm{w}_{1 / 2}=105 \mathrm{~Hz}, 15 \mathrm{H}, \mathrm{C}_{5} \mathrm{Me}_{5}$ ), $17.8\left(\mathrm{br} \mathrm{s}, w_{1 / 2} 55 \mathrm{~Hz}, 18 \mathrm{H}, \mathrm{PMe}_{3}\right.$ ). $\mu_{\text {eff }}=2.94 \mu_{\mathrm{B}}$ by the NMR method in $\left[{ }^{2} \mathrm{H}_{6}\right]$ benzene. An identical procedure was used to isolate solutions of compound $\mathbf{1 b}$. ${ }^{1} \mathrm{H}$ NMR $\left(\left[{ }^{2} \mathrm{H}_{6}\right]\right.$ benzene $\left.T 295 \mathrm{~K}, \delta\right): 71\left(\mathrm{br} \mathrm{s}, \mathrm{w}_{1 / 2}=230 \mathrm{~Hz}, 15 \mathrm{H}, \mathrm{C}_{5} \mathrm{Me}_{5}\right), 16.3$ and $15.3\left(1: 1\right.$ br overlapping $\left.\mathrm{s}, w_{1 / 2}=115 \mathrm{~Hz}, 12 \mathrm{H}, \mathrm{PMe} 2 \mathrm{Ph}\right), 8.9(\mathrm{~s}$, $\left.w_{1 / 2} 22 \mathrm{~Hz}, 2 \mathrm{H}, p-\mathrm{Ph}\right), 7.8\left(\mathrm{~s}, w_{1 / 2} 26 \mathrm{~Hz}, 4 \mathrm{H}, m-\mathrm{Ph}\right), 6.1\left(\mathrm{~s}, w_{1 / 2} 150\right.$ $\mathrm{Hz}, 4 \mathrm{H}, o-\mathrm{Ph})$

\$4a: MS (Cl, negative ions): 448 ([M]- $100 \%$ ), 372 ([M]-- $\mathrm{PMe}_{3}$. $93 \%$; IR (pentane, $\left.\mathrm{cm}^{-1}\right): 1792 .{ }^{1} \mathrm{H}$ NMR $\left(\mathrm{C}_{6} \mathrm{D}_{6}, \delta\right): 1.66(\mathrm{~s}, 15 \mathrm{H}$, $\left.\mathrm{C}_{5} \mathrm{Me}_{5}\right), 1.30$ (virt. $\left.\mathrm{t}, J_{\mathrm{PH}} 4 \mathrm{~Hz}, 18 \mathrm{H}, \mathrm{PMe}_{3}\right) .{ }^{31} \mathrm{P}\left\{{ }^{1} \mathrm{H}\right\} \mathrm{NMR}\left(\mathrm{C}_{6} \mathrm{D}_{6}, \delta\right)$ : 18.5. 4b: MS (CI, negative ions): $572\left([\mathrm{M}]^{-}, 10 \%\right), 434\left([\mathrm{M}]^{-}\right.$-
$\mathrm{PMe}_{2} \mathrm{Ph}, 15.5 \%$ ). IR (pentane, $\left.\mathrm{cm}^{-1}\right): 1793$. ${ }^{\mathrm{H}} \mathrm{H}$ NMR $\left(\mathrm{C}_{6} \mathrm{D}_{6}, \delta\right): 7.79$ $\left(\mathrm{m}, 4 \mathrm{H}, \mathrm{PMe}_{2} P h\right), 7.08\left(\mathrm{~m}, 6 \mathrm{H}, \mathrm{PMe} \mathrm{e}_{2} P h\right), 1.52\left(\mathrm{~s}, 15 \mathrm{H}, \mathrm{C}_{5} \mathrm{Me}_{5}\right), 1.44$ (overlap of two virt. t, $12 \mathrm{H}, \mathrm{PMe}{ }_{2} \mathrm{Ph}$ ). ${ }^{31} \mathrm{P}\left\{{ }^{1} \mathrm{H}\right\} \mathrm{NMR}\left(\mathrm{C}_{6} \mathrm{D}_{6}, \delta\right): 22.0$. A single crystal of $4 \mathrm{~b}$, grown by cooling a soluton in $\mathrm{Et}_{2} \mathrm{O}$ to $-20^{\circ} \mathrm{C}$, was characterized crystallographically: monoclinic $P 2_{1} / c, a=$ 9.572(2), $b=13.461(2), c=21.542(3) \AA, \beta=97.84(2), V=2738$ (2) $\AA^{3}, Z=4, D_{\mathrm{c}}=1.38 \mathrm{~g} \cdot \mathrm{cm}^{-3}, \mu(\mathrm{Mo}-\mathrm{K} \alpha)=7.02 \mathrm{~cm}^{-1}, R=0.0459 ; R_{\mathrm{w}}$ $=0.0551$. Atomic coordinates, bond lengths and angles, and thermal parameters have been deposited at the Cambridge Crystallographic Data Centre. See Information for Authors, Issue No. 1.

\$ 5a: 'H NMR $\left(\mathrm{C}_{6} \mathrm{D}_{6}, \delta\right): 1.76\left(\mathrm{~s}, 15 \mathrm{H}, \mathrm{C}_{5} \mathrm{Me}_{5}\right), 1.32\left(\mathrm{~d}, 18 \mathrm{H}, J_{\mathrm{PH}} 9\right.$ $\left.\mathrm{Hz}, \mathrm{PMc}_{3}\right),-2.83\left(\mathrm{t}, 2 \mathrm{H}, J_{\mathrm{PH}} 50 \mathrm{~Hz}, \mathrm{MoH}_{2}\right) .{ }^{31} \mathrm{P}\left\{\right.$ selective- $\left.{ }^{-1} \mathrm{H}\right\} \mathrm{NMR}$ $\left(\mathrm{C}_{6} \mathrm{D}_{6}, \delta\right): 11.0\left(\mathrm{t}, J_{\mathrm{PH}} 38 \mathrm{~Hz}\right) .5 \mathrm{~b}:{ }^{1} \mathrm{H}$ NMR $\left(\mathrm{C}_{6} \mathrm{D}_{6}, \delta\right): 1.71(\mathrm{~s}, 15 \mathrm{H}$, $\left.\mathrm{C}_{5} \mathrm{Me}_{5}\right), 1.46\left(\mathrm{~d}, 12 \mathrm{H}, J_{\mathrm{PH}} 10 \mathrm{~Hz}, \mathrm{PMe}_{2} \mathrm{Ph}\right),-2.23\left(\mathrm{t}, 2 \mathrm{H}, J_{\mathrm{PH}} 50 \mathrm{~Hz}\right.$, $\left.\mathrm{MoH}_{2}\right),{ }^{31} \mathrm{P}\left\{\right.$ selective- $\left.{ }^{-} \mathrm{H}\right\}$ NMR $\left(\mathrm{C}_{6} \mathrm{D}_{6}, \delta\right): 21.8\left(\mathrm{t}, J_{\mathrm{PH}} 34 \mathrm{~Hz}\right)$.

I Repeating these reduction procedures with ${ }^{1} \mathrm{H}$ NMR monitoring shows that compound 1a is also obtained in significant quantities in both cases, although its higher solubility leads to pure isolated $\mathbf{2}$ and $\mathbf{3}$, respectively.

II A temperature-dependent spin singlet-triplet equilibrium has been reported for the two-legged piano stool $\mathrm{Ni}^{\prime \prime}$ complexes $\left[\mathrm{C}_{5} \mathrm{H}_{5} \mathrm{Ni}\left\{\mathrm{P}(\mathrm{S}) \mathrm{R}_{2}\right\}_{2} \mathrm{Ni}\left(\mathrm{C}_{5} \mathrm{H}_{5}\right)\right]^{12 a}$ and $\left[\mathrm{C}_{5} \mathrm{H}_{5} \mathrm{Ni}\left(\mu-\mathrm{SBu}^{t}\right)_{2}-\right.$ $\left.\mathrm{Mo}\left(\mathrm{C}_{5} \mathrm{H}_{5}\right)_{2}\right]^{+} .{ }^{12 b} \mathrm{The} \mathrm{Fe}(\mathrm{CO})_{4}$ transient also has a spin triplet ground state. ${ }^{13}$

\section{References}

I R. Davis and L. A. P. Kane-Maguire, in Comprehensive Organometallic Chemistry, ed. G. Wilkinson, F. G. A. Stone and E. W. Abel, vol. 3, Pergamon, Oxford, 1982.

2 (a) M. Brookhart, K. Cox, F. G. N. Cloke, J. C. Green, M. L. H. Green, P. M. Hare, J. Bashkin, A. E. Derome and P. D. Grebenik, J. Chem. Soc., Dalton Trans., 1985, 423; (b) F. Abugideiri, M. A. Kelland, R. Poli and A. L. Rheingold, Organometallics, 1992, 11, 1303; (c) F. Abugideiri, M. A. Kelland and R. Poli, Organometallics, 1992, 11, 1311

3 P. D. Grebenik, M. L. H. Green, A. Izquierdo, V. S. B. Mtetwa and K. Prout, J. Chem. Soc., Dalton Trans., 1987, 9.

4 M. Luksza, S. Himmel and W. Malisch, Angew. Chem., Int. Ed. Engl., 1983, 22, 416; E. Gross, K. Jörg, K. Fiederling, A Göttlein, W. Malisch and R. Boese, Angew. Chem., Int. Ed. Engl., 1984, 23, 738.

5 R. T. Baker, J. C. Calabrese, R. L. Harlow and I. D. Williams. Organometallics, 1993, 12, 830.

6 R. H. Hooker, K. A. Mahmoud and A. J. Rest, J. Chem. Soc., Dalton Trans., 1990, 1231.

7 E. Carmona, J. M. Marín, M. L. Poveda, J. L. Atwood and R. D. Rogers, Polyhedron, 1983, 2, 185.

8 S. T. Krueger, R. Poli, A. L. Rheingold and D. L. Staley, Inorg Chem., 1989, 28, 4599; R. Poli, B. E. Owens and R. G. Linck. J. Am. Chem. Soc., 1992, 114, 1302; F. Abugideiri, J. C. Gordon, R. Poli, B. E. Owens-Waltermire and A. L. Rheingold, Organometallics, 1993, 12, 1575

9 M. J. Bunker and M. L. H. Green, J. Chem. Soc., Dalton Trans., 1981, 85; U. Siemeling and V. C. Gibson, J. Organomet. Chem. 1992, 424, 159; J. de la Mata, M. V. Galakhov, M. Gómez and P. Royo, Organometallics, 1993, 12, 1189.

10 M. L. H. Green, P. Mountford and N. M. Walker, J. Chem. Soc., Dalton Trans., 1989. 908; M. L. H. Green and N. M. Walker, J. Chem. Soc., Chem. Commun., 1989, 1865; G. M. Diamond, M. L. H. Green and N. M. Walker, J. Organometal. Chem., 1992. 413, C1; G. M. Diamond, M. L. H. Green, P. Mountford, N. M. Walker and J. A. K. Howard, J. Chem. Soc., Dalton Trans., 1992. 417.

11 B. K. Campion, R. H. Heyn and T. D. Tilley, J. Chem. Soc., Chem. Commun., 1988, 278; (b) T. J. Johnson, J. C. Huffman and K. G. Caulton, J. Am. Chem. Soc., 1992, 114, 2725.

12 (a) W. Kläui, K. Schmidt, A. Bockmann, P. Hofmann, H. R. Schmidt and P. Stauffert, J Organomet. Chem., 1985, 286, 407 (b) H. Werner, B. Ulrich, U. Schubert, P. Hofmann and B. Zimmer-Gasser, J. Organomet. Chem., 1985, 297, 27.

13 J. K. Burdett, J. Chem. Soc., Faraday Trans. 2, 1974, 70, 1599; M. Poliakoff, J. J. Turner, J. Chem. Soc., Dalton Trans., 1974, 2276 T. J. Barton, R. Grinter, A. J. Thompson, B. Davies and M. Poliakoff, J. Chem. Soc., Chem. Commun., 1977, 841. 